\title{
Politics, persuasion and public health in Jamaica, 1800-50
}

Public health exists at the interface between medicine and society, and is therefore as much a political process as a medical one, creating opportunities for both medical practitioners and other interested parties to persuade legislators to adopt or reject certain policies. To examine how public health evolves consequently requires close attention not just to changes in practices and policies but also to the processes by which legislators are persuaded to adopt them. However, as Catherine Kelly and Imogen Goold recently commented in their discussion of legal medicine after 1760, although the role of medical professionals as expert witnesses in trials and inquests is now much better understood, 'very little of this work has considered the ways in which doctors have contributed to the creation of the laws and legal concepts which have been formulated to govern their activities', or broader matters of public health which almost invariably require a legal or legislative basis in order to be effective. ${ }^{1}$ Though many times and periods might serves as case studies for this process, this article looks at the island of Jamaica in the early nineteenth century, and shows how the medical profession tried to persuade the colonial legislature to adopt two public health measures, inspired by changing British practice. It will show that the process was slow and haphazard, and required parties to find persuasive language that could convince legislators to adopt it, in the context of the broader social and economic challenges in the 1830s and 1840s of moving away from a society built on plantation slavery and racial hierarchy towards one of free labour and racial equality.

\section{Historiography}


Both medicine and public health are products of the society from which they emerge, and recent scholarship has emphasised the political and social purposes which often underpin medical measures and institutions. Earlier work in the 1950s by René Sande and George Rosen identified the history of public health as an important area of study but presented it mainly as a technocratic accomplishment, in which dedicated bureaucrats followed developing scientific theory to provide proper sanitation, nutrition and healthcare and to eliminate pollution, contamination, contagion and all other sources of disease and injury. ${ }^{2}$ Officials such as Sir Edwin Chadwick, who oversaw the reform of sanitation in Britain in the mid-nineteenth century in accordance with rational norms, were the exemplars of this process. As the historiography has developed it has demonstrated how the aims and methods of both medicine and public health were actually products of the society out of which they emerged. Asa Brigg's study in 1961 of cholera epidemics in nineteenth century Europe, for example, was the first of numerous studies which emphasised that responses to the disease were filtered through existing social and cultural preconceptions, and that the disease in turn had an impact upon the wider politics and society of the period. ${ }^{3}$ Developing Foucault's study of the prison as a site of social transformation and refashioning, other work has argued that institutions of public health such as hospitals or clinics should be reconceptualised as instruments of social change employed the elites to monitor and reshape resistance. The history of public health is therefore also the history of the policies and practices of public health, what Foucault called the 'bio-politics of population'. Dorothy Porter concluded that 'the history of population health in inherently linked to the history of the operation of power', for instance, '[and] this means examining population health as a political phenomenon in all chronological periods and in different national and international contexts'. More recently, Christopher Hamlin has likewise argued that in the scholarship of public health 'the grand issues of politics, power and possibility remain central'. ${ }^{4}$ 
Where this literature has merged with a growing focus on the imperial experience, the result has often been to show how European institutions of public health were interpreted through, and repurposed for, the racialised concerns of white elites seeking to control non-white populations. For example, Diana Paton, Leonard Smith and Rana Hogarth have demonstrated how British practices of prison reform and institutional care for the sick and insane were adapted by elites in Jamaica to create prisons, workhouses, lunatic asylums and even hospitals that were intended to pathologise black resistance or 'laziness' and reform inmates into productive, obedient labourers. ${ }^{5}$ Institutions such as the Hospital and Asylum for Deserted Negroes created in Kingston in 1776 were therefore 'an emblem of whites' collective control of slaves and freed blacks under the guise of altruism' ${ }^{6}$ Richard Sheridan and Katherine Foxhall have demonstrated how planters adopted vaccination to protect their workforces, while Christienna Fryar has shown how the devastating cholera epidemic of 1850 served to confirm for whites the moral, social and cultural failings of the free black population and the urgent need for both moral and sanitary reform. ${ }^{7}$ Other aspects of public health within Jamaica have remained unexplored though, and very little of the literature has examined the process by which these measures were incorporated into colonial society. This article aims therefore not to contest these earlier studies but to offer two more case studies that will suggest the wider political context in which all of these individual episodes occurred.

This requires firstly a sense of the political architecture of the island of Jamaica and the political processes through which measures for public health were adopted. Until 1866 the island possessed its own legislative assembly with broad powers over most internal matters in the island. ${ }^{8}$ Modelling itself on the Westminster parliament, the house of assembly had about forty members, drawn from the white agricultural and mercantile elite, and any 
legislation had to secure a majority in the house and the support of the imperial governor and the Board of Trade or Colonial Office back in Britain before passing into law. Thus, even if the medical profession were convinced of the need to adopt a measure for public health in Jamaica, it had to persuade the planters and merchants who sat in the assembly. Secondly, understanding how these measures were adopted also requires some understanding of the broader social and economic circumstances. During the eighteenth century the island grew rich from a plantation economy producing sugar for the British and European market, based on the brutal exploitation of black slaves imported from West Africa, and secured by a society which granted substantial privileges to whites and virtually none at all to free people of colour, let alone slaves. All of these elements were undermined between 1800 and 1850 . The abolition of the slave trade in 1807 increased the cost of labour and precipitated a slow process of economic decline. ${ }^{9}$ The emancipation of the slaves in 1834 and the early end to a transition period of indentured service in 1838 wholly undermined the plantation economy and created a new 'public' in Jamaica which was predominantly black and poor rather than white and rich as before. The removal of British duties on foreign sugar in 1846 destroyed what was left of the sugar industry, which could not compete with cheaper slave-grown sugar from Cuba and Brazil, and by 1850 the island was therefore in a state of economic disarray.

The context of the public health measures analysed here was therefore one of economic decline, social unrest and a society divided between conservative white 'Country' planters and a more liberal 'Town' party of white and mixed-race merchants, smallholders and professionals, who were allied for much of the 1830 s with the imperial government. ${ }^{10}$ Medical practitioners had to consider how to persuade legislators whose main concern was the economic condition of the island, the heavy burden of taxes, and a rancorous debate about what a free multi-racial society should look like. As noted already, this had not necessarily prevented the assembly in the past from taking steps to provide public health by setting up 
hospitals or vaccination schemes, when the steps were necessary and the 'public' that they served would benefit. ${ }^{11}$ The issues faced by the medical profession, as the next two sections will show, was instead how to convince the house to employ this power and adopt their proposals. As in Britain, as Catherine Kelly has shown, medical practitioners in Jamaica needed to find plausible languages to persuade individual legislators. ${ }^{12}$

\section{Coroners}

This can be seen, in the first case, in the long and surprisingly bitter attempt to reform the system of coroners and forensic medical witnesses between 1800 and 1850 . This system had been transferred to the island largely unchanged from England, where the coronership was an ancient royal office dating back to the twelfth century and, by the early modern period, responsible for maintaining the King's Peace in the individual counties and examining all

unexplained or anomalous deaths. ${ }^{13}$ The office was often an elected one and there was no real expectation that the coroner would be a medical practitioner, since his duty was essentially to supervise a legal inquest into the death and determine whether a criminal act had been committed, with the help if necessary of expert witnesses such as doctors, who might examine the body and even conduct a post mortem to try to establish the cause of death. In early nineteenth century Britain however there was a growing sense that the coroner could play a wider role in public health by accurately identifying contagious diseases and even holding institutions and companies to account for deaths caused by negligence or corporate irresponsibility. ${ }^{14}$ This principle was strongly promoted in the 1830 s and 1840 s by Thomas Wakley, a medical reformer and general practitioner who hoped that medical coroners and the regular use of medical witnesses at inquests would bring together scientific expertise, social justice and political reform, as well as raising the standing, authority and 
status of the profession. ${ }^{15}$ As Ian Burney has shown, Wakley was resisted by medical and political conservatives, who were not persuaded either by his arguments or their implications, and challenged his contradictory efforts to make the coronership both a fount of scientific authority and a platform for popular justice and political change. ${ }^{16}$

Reform of the system of coroners and medical witnesses in Britain was therefore grounded in a number of languages that combined political, social and medical or scientific reform. As a programme it offered both advantages and disadvantages to medical practitioners in Jamaica. On the one hand, like the formation of the new College of Physicians and Surgeons in 1835 and the Jamaica Physical Journal the previous year, the introduction of medical coroners and witnesses would delineate even more clearly the superior standing of medical science and its practitioners by using this science to protect the public from both disease and crime. The Journal noted in 1835 , for example, that 'innumerable causes of violent deaths would be brought to light and accounted for upon the broad principles of physiological truth instead of the vague, flippant and irrational conclusion that such and such a person died by the visitation of God!'. ${ }^{17}$ It also promised to help support the profession at a moment when it was under threat, since restricting the office of coroner to regularly-qualified medical practitioners would buttress their authority as they competed with druggists, empirics, quacks and obeah-men in the new medical marketplace emerging in the free society of Jamaica. ${ }^{18}$ The fees offered for coroners and medical witnesses could be substantial and could help to make up for some of the losses created as planters ceased to hire doctors to provide medical care for their black workforce.

On the other hand the question was also a political minefield, firstly because it would lay additional financial burdens on the island during a period of economic decline. In the period between 1800 and 1850 the national income of Jamaica halved from about $£ 8$ million a year to less than $£ 4$ million, even as taxation rose, placing much greater financial burdens 
on planters and eventually generating in the 1850s a furious contest for economy, austerity and retrenchment. ${ }^{19}$ As will become clear, proposals that the medical practitioners of Jamaica should receive additional sums would be extremely contentious, not least because the main beneficiaries would not be the white planters but the new free black population. Secondly, as Wakley frequently declared that his medical expertise would be used to enable coroners to hold workhouses and prisons to account for their treatment of the downtrodden and voiceless, the introduction of any similar measures in Jamaica would undermine planters' efforts to control the black population through these institutions. Planters strongly resisted efforts by British abolitionists and the Colonial Office to investigate maltreatment, violence and unsanitary conditions in colonial prisons, for example, leading to a constitutional crisis in 1839 over imperial attempts to reform them. ${ }^{20}$ To suggest that deaths in Jamaican prisons and workhouses should be publicly examined by an independent medical practitioner was thus potentially an explosive proposition, since the usual practice had been for Jamaican coroners to ignore all evidence of maltreatment. ${ }^{21}$

Securing a medical coronership and remuneration for medical witnesses would thus become an exercise in persuasion between 1800 and 1850, in which the profession in Jamaica managed to agree on a common political and public strategy despite coming to the issue from opposing and even contradictory positions. These can be seen very broadly as the 'liberal' position, offered mainly by urban practitioners working in the city of Kingston and its suburbs, and the 'conservative' position offered by the rural or country practitioners elsewhere in the island, whose practice had lain largely with the plantations and were therefore disproportionately affected by the end of slavery and the resort of the black populations to unqualified practitioners. ${ }^{22}$ The organs of the urban practitioners were the Jamaica Physical Journal and various sympathetic liberal newspapers such as the Watchman or Morning Journal, edited by two free men of colour in the assembly, or the Royal Gazette 
and the Kingston Chronicle, which both took a more progressive approach to the question of emancipation and the position of the black population in a free society. ${ }^{23}$ The newspapers representing the planters of Jamaica and the conservative interest in this period were the Jamaica Despatch and the Colonial Standard. The letters and editorials they printed, and their reports of the debates in the assembly, show the different ways these groups went about finding the right languages to persuade members of the assembly to adopt their proposals.

The liberal group of practitioners rooted their argument in a combination of medical and scientific authority as an end in itself and as a boon for the profession. As noted above, the Jamaica Physical Journal carried an editorial in November 1835 which made the case for reform. It opened with a scathing denunciation of "the absurd distinctions, the defective state of the laws relating to the medical profession and the gross abuses of its constituted authorities', and made reference to Wakley and others to show the numerous abuses in Jamaica arising from the lack of scientific rigour in forensic medicine, and closed with a plea for 'something more rational ... which does not harrow up the best feelings of humanity and render us the scorn of other nations while it sinks us beneath the boasted dignity of this enlightened age'. ${ }^{24}$ The reform of the coroners was therefore a project that would support the interests of the population. By July 1836 the Journal was able to report with satisfaction to its readers that measures for reform were afoot in England, where Wakley was introducing his bill into parliament, and also Jamaica, '[as] in one of our early numbers we adverted to this subject, and our observations have been quoted and appreciated'. ${ }^{25}$ A letter to the Royal Gazette in September 1836 from 'A Country Practitioner' living at 'Poverty Hill' in the parish of St George's exemplified the conservative position, praising the Journal for raising the subject and pointing out that the demand in particular for medical witnesses to receive adequate compensation would help to support doctors whose practiced in rural areas. ${ }^{26}$ Rural 
practitioners would support efforts to reform the coroners, but for the sake of their own finances rather than for the black public.

This can be seen more clearly in the arguments presented by both the liberal and the more conservative medical practitioners when a bill for reforming the qualifications for medical witnesses and coroners was introduced into the assembly on 3 November 1836 by Dr Benjamin Whittaker, a conservative rural practitioner. ${ }^{27}$ The newspapers reported that he 'dilated on the hardship under which members of his profession laboured' when they were forced to attend court cases or coroners' inquests without adequate or speedy compensation. Subsequent debates demonstrated that most of the members were in fact willing to accept the argument that medical testimony was a necessity at inquests, but disagreed as to whether practitioners should receive any compensation. The conservative planters $\mathrm{Mr}$ Leslie and $\mathrm{Mr}$ Frater 'did not see why medical men should be remunerated in preference to jurors, whose duties were just as arduous and unpleasant'. ${ }^{28}$ William Jordon, one of the editors of the Watchman and the Morning Journal, pointed out that Kingston already remunerated its medical witnesses. When the bill was read again in committee on 29 November these arguments were repeated. 'Some members argued against gentlemen of the medical profession being placed in a better situation than other persons who were obliged to perform that duty without fee or reward', the Watchman reported, '[and] others contended that when they were taken from their business, for the purpose of giving opinions by which the jury were to be governed in their verdict, it was only fair that they should be remunerated' ${ }^{29}$ An amendment was proposed by conservative members to halve the mileage allowance while also making attendance compulsory, and the planter Alexandre Bravo turned the arguments made by the doctors against them, saying that attendance was professional obligation and 'honourable and essentially necessary to keep up their anatomical knowledge' ${ }^{30}$ 
The initial attempt to reform the law on coroners and medical witnesses in 1836 was therefore supported by both liberal and conservative practitioners but failed to find the right arguments to persuade the members of the assembly, who brought their own concerns about economy and retrenchment to the discussion and decided to pass the bill with its reduced mileage allowance. The liberal lawyer and planter Fitzherbert Batty claimed the result was a slur on the medical profession, because the allowance was no more than a postman or policeman received. ${ }^{31}$ Whittaker undoubtedly did not help matters by asking to withdraw the bill '[as] the committee had so mutilated it that he cared not seeing it passed in its present form', and also by showing his disdain for the medical knowledge of lay jurors at inquests, declaring that 'he knew ... that there would sometimes be a parcel of boobies who would not make up their minds until the appearance of a medical man, who in two words would decide the verdict'. ${ }^{32}$ The failure of the medical profession to find the right languages of persuasion to effect this measure for public health is demonstrated by the response of the Watchman, which might have been expected to support any measure carrying such liberal credentials in Britain and calculated, at least superficially, for the benefit of the black population in Jamaica. 'It appears to us that the opposition [by Whittaker] was not quite fair', it wrote, 'because whilst we desire to remunerate medical men it should be kept in mind that the bill will entail a heavy expence on the parishes, many of which are not in a condition to bear it' ${ }^{33}$ It noted that medical men already received over $£ 3$ for carrying out autopsies, that parishes might have to pay out large sums in mileage if the original bill passed, and that practitioners in England did not receive much more.

Even though both the liberal and conservative medical practitioners were careful to avoid any mention of social justice, and managed to persuade the assembly of the value of proper medical testimony in any inquest, they therefore lacked the proper languages to persuade the house in 1836. By contrast, when the question was put before the assembly 
again in 1840 it was handled more judiciously and moderately, and therefore enjoyed more success. A bill was introduced on 27 March by Charles McClarty Morales, a conservative medical practitioner and member of the assembly for the rural parish of Hanover. He had bipartisan support from the Royal Gazette, which had editorialised a few weeks before that the recent proliferation of quacks and empirics - many of them untrained black practitioners ministering to the rest of the black population with traditional African remedies and spiritualism - could only be halted by introducing medical coroners, "whose duty it will be to expose and bring to justice everyone concerned where a sudden death has taken place from undue influence or malpractice of uneducated men'. ${ }^{34}$ Though the bill faced opposition on the grounds of cost, Morales was able to face it down by pointing out that Wakley's bill in Britain had recently been passed, and the main question was whether or not the house had time to debate the bill properly before the end of the session. ${ }^{35}$ Morales admitted that he had introduced the bill 'so as to take the sense of the Honourable Members, and then let it lay over'. ${ }^{36}$ When the bill was introduced again in October 1841 it therefore passed relatively smoothly. The Morning Journal ran a short editorial soliciting opinions from the public for the benefit of the house, but did not receive any, and Morales agreed that he would abandon his demands for medical coroners because there was no support for this in the island. ${ }^{37}$ The act passed on 31 December confirmed that medical witnesses could be compelled to attend but offered higher allowances, including $2 \mathrm{~s} 6 \mathrm{~d}$ per mile and $£ 5$ for a post mortem, and in that respect offered a modest boon both for public health and the profession in Jamaica. ${ }^{38}$

This did not of course represent the end of the matter. The expiry of the bill in 1845 led to renewed controversy over fees for medical witnesses and coroners and a series of clashes with the British government that was only finally resolved with two further bills in 1849 and $1850 .{ }^{39}$ Evidence taken in 1852 after a cholera epidemic revealed that the impact of these measures was mixed. The Report submitted by the Central Board of Health concluded 
that 'general opinion' was that the office should be held by a medical man, 'the advantages ... being ... numerous and evident' ${ }^{40}$ In most cases the witnesses they interviewed agreed that the office should be restricted to medical practitioners, but for the same mixture of scientific and financial reasons seen in the $1830 \mathrm{~s} .{ }^{41}$ Other witnesses, both medical and lay persons, thought that a medical coroner would save time and money at inquests. ${ }^{42}$ None mentioned explicitly how the coroner might serve to protect the black population from mistreatment at the hands of white planters or state prisons and hospitals, or otherwise act as a force for social justice, as Wakley had hoped the office might in Middlesex. The language of reform was likewise missing in the final act of 1855, which banned the election of lay coroners except in cases when no medical practitioners put themselves forward for election. ${ }^{43}$ Moderate reform of the office therefore took over twenty years and relied on practitioners finding the right set of arguments to persuade the house, in this case by offering the necessary concessions to economy and removing all traces of the radical demands which had informed Wakley's campaign in Britain, creating in turn a series of scandals about maltreatment in the Kingston Lunatic Asylum in 1860 which a more reformist and less conformist system of coroners might have detected or prevented. ${ }^{44}$

\section{Quarantine}

When medical practitioners were unable even to agree on the proper medical policies to adopt, let alone the right languages of persuasion, their measures for public health could fail utterly, as the history of quarantine in Jamaica can show. Mark Harrison and others have demonstrated that the West and East Indies were testing grounds between 1800 and 1850 for many new medical theories of infection and the measures necessary to contain epidemic diseases such as yellow fever, smallpox and cholera. ${ }^{45}$ Practitioners increasingly rejected 
theories of contagion, focussing instead on sanitary reforms that would prevent miasmas and epidemics. This intersected with an important strain of political radicalism in the United States and Britain which brought together free trade, free movement and political freedom. ${ }^{46}$ The cholera epidemic of 1831-2 in Britain seemed to confirm their arguments about the ineffectiveness of quarantine, and medical opinion in the 1840 and 1850 s therefore acquired an anti-contagionist line which often overlapped with political radicalism. Christienna Fryer has recently argued that this approach was introduced into Jamaica by Dr Gavin Milroy in the wake of the cholera epidemic of 1850 and 1851, when he was sent there by the Colonial Office to discover its causes. ${ }^{47}$ She argues that Milroy collected evidence to confirm his arguments, but also that these were embraced by the white elite, since they seemed to confirm their own preconceptions about the uncivilised state of the free black population and the urgent need for firm measures of sanitary (and thus moral) reform. This section argues that large parts of the Jamaican medical and political elite rejected Milroy's arguments, not because they were unsympathetic to his condescending views of the black population but because they were unwilling to spend money reforming them.

Quarantine measures had developed in an ad hoc fashion in Jamaica in the eighteenth century, apparently through orders enacted as necessary by the Governor and council, though the assembly did pass an act in 1732 temporarily preventing the disembarking of slaves infected with smallpox at any of the island's ports. ${ }^{48}$ The first substantive legislative measure came in March 1801 when the assembly passed an comprehensive act 'to oblige ships and other vessels coming from foreign parts, [and] infected with malignant fevers or contagious distempers, to perform quarantine, and for preventing the spreading of infection in this island' ${ }^{49}$ The context was the series of devastating yellow fever epidemics in Jamaica and the surrounding islands, and the legislation the house passed was modelled on British practice. ${ }^{50}$ Vessels arriving at the island from infected ports were to be placed in quarantine 
with their passengers and goods, and to remain under quarantine without any communication with the shore for a set period. The act envisaged that customs officials would inspect the ships but allowed the Governor to appoint other persons to do so, and by 1817 these Health Officers had become so commonplace that the assembly enacted a law which established fees for their remuneration and required them to have medical qualifications of some sort. ${ }^{51}$

Thus, despite Jamaica serving as an experimental laboratory for British practitioners to develop and test their hypotheses about the nature of yellow fever and contagion, when it came to public health in the island political opinion remained as resolutely orthodox as in Britain in the same period. During the cholera epidemic of 1831 and 1832, for example, both the governor and the assembly immediately adopted the same combination of quarantine and sanitary reform used in Britain. The island was already suffering from a smallpox epidemic, and in late December 1831 the slave population had erupted into the largest revolt in Jamaica since 1760, requiring the closest attention of the colonial government for the several weeks it took to suppress it. The arrival of a circular from the Colonial Office warning of the spread of cholera and recommending quarantine probably chimed well with the sense of insecurity and fear of foreign ideological infection among the white population. The governor convened a meeting on 28 December of the magistrates and doctors of Kingston, chaired by the mayor Thomas Yates, which resolved that the quarantine laws should be strictly enforced by the Health Officer, '[as] unless the greatest vigilance was observed by that officer nothing would be easier than the introduction of this awful contagion into this port' ${ }^{52}$ The meeting agreed also the need for a Board of Health to monitor the situation, which the governor and council duly created, and measures for cleaning the streets of Kingston and other towns of rubbish that might cause infection. This was adopted on 13 February by the corporation of Kingston, who agreed 'the necessity of adopting such preparatory measures as shall be deemed most requisite in the exigency that has arisen from the possible introduction of the 
cholera morbus into this community'. ${ }^{53}$ It was also endorsed by the Watchman, who noted that medical opinion was divided on the subject of contagion and that even if quarantine were to be found ineffective, infection could be avoided by proper sanitation. ${ }^{54}$

Both conservative bodies such as the corporation of Kingston and liberal voices such as the Watchman therefore urged a mixed set of measures during the 1831 epidemic, and although the Watchman's initial editorials suggest an understandable affinity for the medically reformist and political liberal anti-contagionist approach, later editorials were far more conservative. On 28 March, for example, the newspaper noted that Health Officers in the island should take particular care to prevent cholera entering the island by contagion: 'the public look up to him ... for that strict and conscientious discharge of their duties which the threatening appearance of things demands'. ${ }^{55}$ Three days later, the editors argued that they were against unnecessary quarantine regulations but wanted strict enforcement of the law against vessels arriving from infected ports. 'It is true that the mercantile interest will be inconvenienced', they concluded, 'but that inconvenience is but as dust in the balance when compared with the awful ravages which is likely to follow the introduction into this town and island of the cholera morbus' ${ }^{56}$ On 4 April it argued that the British government had still not thought it prudent to abandon the practice of quarantine, '[and so] neither ought we, under the circumstances, to dispense with the precaution'. ${ }^{57}$ When fears of another epidemic resurfaced in August the corporation of Kingston repeated its instructions for cleaning the city, 'to guard against all impurities in the air so as to prevent as much as possible the spreading of contagious infection or disease', while the governor once again imposed a strict quarantine. ${ }^{58}$ In March 1832 and again in November bills were introduced by Yates and liberal planters to repeal the quarantine laws and make other provisions, which were both defeated, though as these bills have not survived it is unclear whether they were calling for stricter or looser measures. ${ }^{59}$ 
Even the end of slavery in 1834 and indentured service in 1838, which, among many other effects, encouraged the planters of the island to throw their support behind the wholesale importation of immigrant labourers from West Africa and 'coolies' from India, did not change attitudes towards quarantine and contagion. ${ }^{60}$ When a smallpox scare in 1840 encouraged the assembly to revisit and revise the existing regulations for quarantine, the committee, containing both liberals and conservatives, laid before the house a bill that broadly upheld existing practice. ${ }^{61}$ The bill allowed the governor and council to place suspected vessels, persons and goods in quarantine for as long as they deemed necessary, ordered the Health Officers to inspect ships for infectious diseases, introduced heavy penalties for disobedience, replaced the officers' fees with fixed salaries, and gave the governor carte blanche 'to make such orders, rules and regulations as shall appear to him expedient or necessary for the prevention ... of the spreading of such infectious disease or distemper in this island'. ${ }^{62}$ Alexandre Bravo and conservative planters opposed the bill, but only because it gave such generous salaries to Health Officers during a time of fiscal retrenchment. ${ }^{63}$ The Morning Journal came down on the side of the quarantine bill and urged quarantine when an infected ship arrived in November, while the conservative merchant Hector Mitchel, as the mayor of Kingston, both introduced the quarantine bill into the assembly and issued a municipal proclamation in October warning of the risks of contagion and urging vaccination. ${ }^{64}$ In 1845 the house passed a bill for the building of a lazaretto for quarantine in Kingston harbour, 'for the more effectual carrying out' of the 1840 Act. $^{65}$ In the 1840s both conservative and liberal groups therefore continued to favour a common-sense combination of stricter quarantine and sanitary measures.

This provides the necessary context to assess Fryar's description of responses to the cholera epidemic in Jamaica of 1850 and 1851. She emphasises the importation of anticontagionist doctrine by Milroy, who founded abundant confirmation for his own theories 
that cholera and other diseases were products of filth and poor sanitation, and the adoption of similar rhetoric by various local authorities such as the Central Board of Health, which produced a report for the assembly in 1853 that mirrored Milroy's in most respects. ${ }^{66}$ Both condemned the quarantine law of 1840 as flawed in both theory and practice. 'The Board of Health are convinced from a consideration of the history and theory of quarantine that the fundamental principles upon which its practice is based are erroneous', they concluded, for instance, '... [and] are of opinion that the quarantine laws as at present conducted are an irksome encumbrance, interrupting commerce, obstructing national intercourse, periling life, fostering and engendering disease, and squandering large sums of public revenue'. ${ }^{67}$ Both also urged the need for better sanitation and medical care for the black population, and a programme of moral education by a paternalistic state that would make them into responsible subjects. 'The government must on such occasions if need be exercise a paternal authority', the Board concluded, '[and] the mass of the people must be taught the necessity of these measures by precept and example'. ${ }^{68}$ This was the outcome of close process of collaboration between the Board and Milroy, who had persuaded the assembly to bring the board into existence on his arrival in Jamaica in January 1851, and participated in most of its meetings. ${ }^{69}$ They formed a cooperative nexus which made a case for the relaxation of quarantine, apart from those individuals showing symptoms of disease, and an ambitious series of sanitary reforms in the island.

However, it is also clear that Milroy and his anti-contagionist views had such impact because the Board represented a broader set of both political and medical interests in Kingston who were receptive to these ideas and needed very little persuasion to adopt them. As noted above, Kingston had received a Board of Health during the earlier cholera epidemic in 1831 and the corporation had ordered various sanitary measures to prevent infection. Paton and Smith have shown that the corporation under Hector Mitchel as mayor became 
increasingly conservative in the 1840 s, using the municipal prison, workhouse and lunatic asylum as institutions to address the perceived idleness of the transient black population in the city. ${ }^{70}$ In November 1849 the Board of Health had written to Mitchel as mayor of Kingston stating the need for wholesale sanitary reform and the wholly ineffective nature of quarantine measures, though they added that they should not abandon those specific ones 'such as prudence, rather than science, suggests'. ${ }^{71}$ A bill had been introduced into the house to repeal parts of the quarantine act. ${ }^{72}$ As the Central Board of Health was drawn largely from the political and medical elite of Kingston, including Mitchel, it is therefore perhaps no surprise that the Board did not require much persuasion by Milroy. He in turn commended their actions and blamed the colonial government and assembly for failing to act on the 1849 letter, 'notwithstanding the remonstrances of the medical profession in Kingston and the warning in the admirable letter ... to the civic authorities'. ${ }^{73}$ The board of health had been useless in 1831, but only due to a lack of adequate support, and the political and medical elites of Kingston had done their utmost to provide medical care and sanitation, '[and] their conduct deserves all praise' ${ }^{74}$ Another 'very able' petition requesting sanitary reform had been submitted by them to the assembly in December 1850, which the house had then ignored. ${ }^{75}$ His survey of the state of Kingston emphasised its wholly unsanitary state and noted areas where the city corporation was lax, but praised the 'respectable inhabitants' of Kingston for their efforts to effect sanitary reform. ${ }^{76}$ He blamed the governor for appointing a Board of Health in Kingston which lacked the powers to effect proper reforms. ${ }^{77}$

Milroy was thus pushing at an open door at the Central Board of Health in Kingston in 1851, which had already, for the reasons Fryar has described, moved away from a set of measures based on quarantine and towards one based on sanitary reform and a close regulation of black conduct. His intervention offered scientific and medical authority and enabled the Board to condemn contagionists as 'persons who promote theories, the bantlings 
of their own limited knowledge and still more limited experience ... [and] give risen to opinions directly opposed to those emanating from authorities, persons whose opportunities of judging have been much greater than theirs' ${ }^{78}$ In return, the Board helped Milroy to secure the evidence he needed to offer a more convincing case to anti-contagionists in Britain, even going to the extent of suppressing inconvenient contrary evidence. For example, having asserted that the quarantine laws were being relaxed as unnecessary by most European nations ${ }^{79}$, the Board reported in 1853 that they had also found from interviews with the several Health Officers of the island that the laws were unworkable, 'and not in accordance with the views at present entertained on this subject by the most enlightened nations on Earth' ${ }^{80}$ This was tendentious at best. Certainly the Health Officer for Kingston, Richard Chamberlaine, had testified that the system was inadequate and restricted the liberty of persons unduly, and had even published a letter in the Colonial Standard arguing that the cholera epidemic was local and not imported. Yet although he knew that quarantine had in effect been abolished in Britain, 'under the free trade laws and regulations', he drew back from this 'rather unsafe and a dangerous experiment ... [namely] the substitution of sanitary measures alone for quarantine restrictions, as recommended by the General Board of Health of England'. ${ }^{81}$ Other Health Officers argued that the laws would prevent contagion if they were properly enforced by the island. ${ }^{82}$ For instance, the Health Officer at Morant Bay stated that 'I am no advocate for doing away with quarantine regulations, as I conscientiously believe them to be a safeguard to public health', but this was not reflected in the Report. ${ }^{83}$ Milroy and the Central Board of Health in Jamaica therefore formed a tight nexus of mutual persuasion, but by relying on Milroy's report Fryar arguably overstates both the extent of this nexus and the success of Milroy in finding the right languages to use to persuade others. Medical practitioners outside Kingston might have supported any arguments for closer regulation of black labourers, but not when this clashed with their own experience 
of rural cholera, or required expensive public health measures that the island could not afford in a period of economic decline and major financial retrenchment. For instance, Dr William Dutton Turner, the president of the Jamaica College of Physicians and a member of the Central Board of Health, dissented from its published advices of July 1851 'which infer the doctrine of non-contagion, and all matters founded on that opinion' ${ }^{84}$ Significantly, Turner was not based in Kingston but in the rural parish of St Catherine, and the Report was also later opposed by Dr Hinton Spalding, a planter and medical practitioner in the rural parish of Metcalfe. ${ }^{85}$ The Colonial Standard and Jamaica Despatch, a conservative and rural proplanter newspaper, was less impressed with Milroy's reports than the Central Board of Health in Kingston. An editorial in March 1851 argued that his report was neither instructive nor useful. 'We are told what we had long before learnt from other official and scientific sources', it noted, and then complained that Milroy offered only expensive and impractical measures such as the wholesale removal of population from unhealthy areas. ${ }^{86}$ When a liberal bill offering more money for proper sanitary measures was debated in May 1851, Spalding openly opposed it, arguing it would 'impose a very considerable expence on the country', especially because cholera was not contagious, and 'the rigid enforcement of the present quarantine laws, with a vigilant performance of duty of the medical Board of Health in Kingston, would be all that is required for the prevention of the disease', rejecting Milroy's argument and its implications. ${ }^{87}$ So inflammatory and unrealistic was the anti-contagionist report of the Central Board of Health in 1853, the house refused to print it. ${ }^{88}$

Milroy and the Board equally failed to persuade the colonial governor, judging from his letter to the Colonial Office in September 1853, which accused them of ignoring wider circumstances and local medical experience. ${ }^{89}$ The island was bankrupt, and any taxes for spending on sanitation would have to pass through a hostile assembly, '[and] public opinion here', he said', 'and I believe I may also say in England, is still much divided on the subjects 
of contagion and quarantine'. Though not contesting Milroy's medical qualifications, the governor noted that Dr Turner and Dr Spalding had both disagreed with Milroy's conclusions, 'in very decided terms', and argued 'the local experience of each of those two physicians and his personal acquaintance ... with the diseases of Jamaica has been beyond comparison greater than that of any of those who have signed the report'. ${ }^{90}$ The governor's sentiments were echoed by his successor in 1854, who felt that Milroy's measures were necessary only for urban areas such as Kingston, and might not be passed at all by a colonial legislature concerned mainly with retrenchment. ${ }^{91}$ Though conservative planters might have sympathised with Milroy's arguments that the black population were in no condition to look after themselves, he and the Board, composed mainly of urban groups, failed to persuade conservative rural planters that the assembly should invest heavily in public health and proper sanitation, and thus they either ignored his theories or rejected them. The quarantine laws remained in place until 1857 , and the programme of sanitary reform and medical provision that Milroy had proposed was never adopted..$^{92}$

\section{Conclusion}

Examining how two different measures for public health were reformed in Jamaica in the early nineteenth century therefore makes a number of suggestive points about the role of politics and persuasion in the creation and operation of public health measures, fulfilling Kelly and Goold's suggestion about the need now 'to explore how medical practitioners played a role in shaping the laws to which they were subject ... [and] how the requirements, limitations and intellectual structure of the British legal process shaped medicine and medical practice'. ${ }^{93}$ The first is that practitioners adopted these measures for various reasons. Wakley pushed hard for medical coroners in Britain as an aspect of his broader campaign for 
social justice and political reform, whereas in Jamaica conservative practitioners took the political lead in pressing for reforms that would improve their status and finances in a period of decline. Secondly, arguments used to persuade the Jamaican legislature to adopt certain policies varied greatly with circumstances. Although the campaign against quarantine in Britain was very closely linked with political reform and free trade, none of this rhetoric appeared to Jamaica in 1851, almost certainly because of the catastrophic impact of free trade laws in 1846 on what remained of the plantation economy. Instead, the discussion largely took place between various political factions over whether the benefits of reforming the sanitary conditions of the black population were sufficient to justify the costs of it. Thirdly, as this suggests, the various arguments put forward by medical practitioners had to compete with arguments from other groups which addressed other priorities, such as economic decline, financial retrenchment and the responsibility of the white planter elites in Jamaica to their black labourers, and which frequently proved more persuasive. With both coroners and quarantine, even conservatives in Jamaica were often willing to accept the scientific and medical arguments put forward by reformers, and instead opposed the bills in more persuasive grounds of economy and austerity.

This suggests in turn the need to reassess and contextualise, though by no means to discard, the scholarship noted earlier on other examples of public health reform in Jamaica and the British West Indies during the eighteenth and nineteenth centuries. As Fryar, Paton, Smith, Hogarth and many others have shown, changing ideas in Britain, the United States and further afield about sickness, disease, fertility and the body more generally, and the institutions such as prisons, workhouses, hospitals and lunatic asylums intended to manage and contain populations, were often eagerly received and implemented in Jamaica and elsewhere. Sometimes the ideas required no modification at all, but in other instances they were adapted to fit the particular circumstances of plantation slavery and a creole society 
built on hierarches of race, class and gender. The examples studied here demonstrate that the process was not automatic. Simply because an idea was useful and available did not mean that it would be adopted, either by the island in general or by the medical profession itself. Competing ideas and arguments circulated throughout islands such as Jamaica, and active persuasion was often required by the medical profession to convince planters that certain measures for public health should be adopted in preference to others. In considering the benefits of new prison discipline or sanitary measures, planters and practitioners were assessing not only the value of these ideas in isolation but also in relation to a range of other ideas and arguments that might more closely match other priorities. Public health therefore became an exercise in politics and persuasion, as interest groups competed to convince others that their own arguments were a better way to address the problems that seemed to confront society in the island.

\footnotetext{
1 Imogen Goold and Catherine Kelly, 'Introduction: lawyers' medicine: the interaction of the medical profession and the law, 1760-2000', in Imogen Goold and Catherine Kelly (eds.), Lawyers' medicine: the legislature, the courts and medical practice, 1760-2000 (Oxford; Portland, OR, 2009) p. 3

2 Dorothy Porter, 'The history of public health: current themes and approaches', Hygiea Internationalis, 1 (1999) pp. 9-21; Christopher Hamlin, 'Public health', in Mark Jackson (ed.), The Oxford Handbook of the History of Medicine (Oxford, 2011) pp. 411-28

3 Asa Briggs, 'Cholera and society in the nineteenth century', Past \& Present 19 (1961) pp. 76-96; Richard Evans, 'Epidemics and revolutions: cholera in nineteenth-century Europe', Past \& Present 120 (1988) pp. 12346.
} 
4 Porter, 'Current themes', p. 21; Hamlin, 'Public health', p. 422

5 Diana Paton, No bond but the law: punishment, race, and gender in Jamaican state formation, 1780-1870 (Durham, NC; London, 2004) pp. 1-155; Leonard D. Smith, Insanity, race and colonialism: managing mental disorder in the post-emancipation British Caribbean, 1838-1914 (Basingstoke, 2014) pp. 12-48; Christienna D. Fryar, 'Imperfect models: the Kingston Lunatic Asylum scandal and the problem of postemancipation imperialism', Journal of British Studies, 55 (2016) pp. 709-27; Rana Hogarth, 'Charity and terror in eighteenthcentury Jamaica: the Kingston Hospital and Asylum for Deserted 'Negroes", African and Black Diaspora: an international journal, 10 (2017) pp. 281-98

6 Hogarth, 'Charity and terror', p. 282

7 Katherine Foxhall, 'The colonial travels and travails of smallpox vaccine, c. 1820-1840', in Catherine Cox and Hilary Marland (eds.), Migration, health and ethnicity in the modern world (London, 2013) pp. 83-103; Richard B. Sheridan, Doctors and slaves: a medical and demographic history of slavery in the British West Indies, 16801834 (Cambridge, 1985) pp. 250-67; Christienna D. Fryar, 'The moral politics of cholera in postemancipation Jamaica', Slavery \& Abolition, 34 (2013) pp. 598-618

8 For studies of the politics and society of the island between 1800 and emancipation in 1834, see Kamau Brathwaite, The development of Creole society in Jamaica, 1770-1820 (Oxford, 1971) ; Christer Petley, Slaveholders in Jamaica: colonial society and culture during the era of abolition (London, 2009) . For the period between 1834 and 1850, see William A. Green, British slave emancipation: the sugar colonies and the great experiment, 1830-1865 (Oxford, 1976) pp. 163-89, 295-326, 353-79; Thomas Holt, The problem of freedom: race, labor and politics in Jamaica and Britain, 1832-1938 (Baltimore, MD; London, 1992) 9 Douglas Hall, Free Jamaica 1838-1865: an economic history (New Haven, CT, 1959) pp. 40-120; Gisela Eisner, Jamaica, 1830-1930: a study in economic growth (Manchester, 1961) pp. 189-200; Green, British slave emancipation pp. 191-251

10 See above n. 8 and also Swithin Wilmot, 'Political developments in Jamaica in the post emancipation period, 1838-1854', (Unpublished DPhil thesis, University of Oxford, 1977); Gad J. Heuman, Between Black and White: race, politics, and the free coloreds in Jamaica, 1792-1865 (Westport, Conn, 1981).

11 For a broader discussion of medicine in Jamaica up to Emancipation in 1834, and then from Emancipation to 1850, see Sheridan, Doctors and slaves and Nadine Wilkins, 'Medical services in Jamaica, 1834-50', (Unpublished MA thesis, University of the West Indies, Mona, 1987). For a shorter but more accessible 
statement of Wilkins' conclusions, see idem., 'Doctors and ex-slaves in Jamaica, 1834-1850', Jamaican Historical Review, 17 (1991) pp. 19-30

12 Catherine Kelly, 'Parliamentary inquiries and the construction of medical argument in the early 19th century, 1793-1825', in Goold and Kelly (eds.), Lawyers' medicine pp. 17-38

13 R.A Houston, The coroners of northern Britain c. 1300-1700 (London, 2014) pp. 1-21

14 Joe Sim and Tony Ward, 'The magistrate of the poor? Coroners and deaths in custody in nineteenth-century England', in Michael Clark and Catherine Crawford (eds.), Legal medicine in history (Cambridge, 1994) pp. 245-67; Ian A. Burney, 'Making room at the public bar: coroners' inquests, medical knowledge and the politics of the Constitution in early-nineteenth century England', in James Vernon (ed.), Re-Reading the Constitution: new narratives in the political history of England's long nineteenth century (Cambridge, 1996) pp. 123-53. The role of the coroner in public health remains a matter of debate: see C.R. Mcgowan and A.M. Viens, 'Reform of the coroner system: a potential public health failure', Journal of Public Health, 32 (2010) pp. 407-10 15 Edwina Sherrington, 'Thomas Wakley and reform, 1823-62', (Unpublished DPhil thesis, University of Oxford, 1973), pp. 141-52, 175-80, 203-50, 276-97; Elisabeth Cawthon, 'Thomas Wakley and the medical coronership - occupational death and the judicial process', Medical History, 30 (1986) pp. 191-202 16 Ian A. Burney, 'Medicine in the age of reform', in Arthur Burns and Joanna Innes (eds.), Rethinking the Age of Reform: Britain, 1780-1850 (Cambridge, 2003) pp. 163-81; Ian A. Burney, 'The politics of particularism: medicalization and medical reform in nineteenth-century Britain', in Roberta Bivins and John V. Pickstone (eds.), Medicine, madness and social history: essays in honour of Roy Porter (London, 2007) pp. 46-57 17 Jamaica Physical Journal, November and December 1835, pp. 464-80, [William Arnold], 'Some remarks on medical jurisprudence, with a view to point out the absurdity of the verdicts too frequently returned on coroners' inquests, proving the absolute necessity for the presence of a medical man on such occasions'. Quotation on $\mathrm{p}$. 465. The editorial was reprinted in Royal Gazette, 26 December 1836, 'Some remarks on medical jurisprudence'.

18 See below n. 22 .

19 See above nn. 8, 9. Provisional estimates of national income and taxation for 1800 to 1830 are provided in Aaron Graham, 'The colonial sinews of imperial power: the political economy of Jamaican taxation, 1768-1838', Journal of Imperial and Commonwealth History, 45 (2017) pp. 198-201 20 Paton, No bond pp. 84, 118-20; Green, British slave emancipation pp. 164-70 
21 Vincent Brown, The Reaper's garden: death and power in the world of Atlantic slavery (Cambridge, MA, 2008) pp. $78-81$

22 For the state of the medical profession in Jamaica between 1800 and 1850, see Sheridan, Doctors and slaves pp. 42-52; Wilkins, 'Medical profession', pp. 27-32

23 William Laurence Burn, Emancipation and Apprenticeship in the British West Indies (London, 1937) p. 273;

Swithin Wilmot, 'From bondage to political office: blacks and vestry politics in two Jamaican parishes,

Kingston and St David, 1831-1865', in Kathleen E.A. Monteith and Glen Richards (eds.), Jamaica in slavery and freedom: history, heritage and culture (Kingston, Jamaica, 2002) p. 313; Petley, Slaveholders in Jamaica p. 72

24 See above n. 17.

25 Jamaica Physical Journal, July and August 1836, pp. 342-3, 'Medical Witnesses Bill'

26 Royal Gazette 10 September 1836, 'To the Editor’

27 Watchman, 5 November 1836, 'Medical Remuneration'; Kingston Chronicle, 3 November 1836, 'Medical

Witnesses Bill'; Royal Gazette, 12 November 1836, 'Proceedings in the House of Assembly' [hereafter

'Proceedings'], 3 November 1836.

28 Kingston Chronicle 12 November 1836, 'Proceedings'

29 Watchman, 3 December 1836, ‘Proceedings' for 29 November 1836, 30 November 1836; Royal Gazette 10

December 1836, 'Proceedings', for 29 November 1836

30 Ibid.

31 Ibid.

32 Ibid.

33 Watchman, 3 December 1836, 'Editorial'

34 Royal Gazette, 7 March 1840, 'Editorial'

35 Jamaica Despatch 8 April 1840, 'Proceedings', 1 April 1840; Morning Journal 8 April 1840, April 1840

36 Jamaica Despatch 8 April 1840, ‘Proceedings’ for 1 April 1840

37 Morning Journal 30 October 1841, 'Proceedings' for 29 September 1841, and 2 November 1841, 'The Coroners Bill’; TNA, CO 140/130 pp. 409, 421, 449

38 TNA, CO140/131 pp. 182, 196; CO140/132 pp. 32, 66, 79, 96, 303, 329, 331-2, 372; 5 Vic. c. 33

39 Details of this controversy can be found in the Votes of the house for 1845 to 1850 , and the correspondence of the governor with the Colonial Office for the same period. 
40 Report by the Central Board of Health of Jamaica (Spanish Town, Jamaica, 1852) [hereafter CBH Report] p. 270

41 CBH Report, p. 197

42 CBH Report, pp. 211-12

4319 Vic c. 17. All references to laws are to Jamaican laws. Copies of the acts can be found in The Laws of Jamaica, (7 vols., St Jago de la Vega, Jamaica, 1802-24) and The Laws of Jamaica (various vols, Jamaica, 1824 onwards).

44 Margaret Jones, 'The most cruel and revolting crimes: the treatment of the mentally ill in mid-nineteenth century Jamaica', Journal of Caribbean History, 42 (2008) pp. 290-309; Smith, Insanity pp. 49-72; Fryar, 'Imperfect models', pp. 709-27

45 Mark Harrison, Medicine in an age of commerce and empire : Britain and its tropical colonies, 1660-1830 (Oxford, 2010) pp. 1-25; Sheridan, Doctors and slaves pp. 11-28 46 Harrison, Medicine in an age of commerce and empire : Britain and its tropical colonies, 1660-1830 pp. 255-86; idem., Contagion: how commerce has spread disease (New Haven, CT, 2012) pp. 50-106; Krista Maglen, The English System: quarantine, immigration and the making of a Port Sanitary zone (Manchester, 2014), esp. pp. 21-59

47 Fryar, 'Moral politics', pp. 598-618; Kenneth F. Kiple, 'Cholera and race in the Caribbean', Journal of Latin American Studies, 17 (1985) pp. 157-77; Rita Pemberton, 'Dirt, disease and death: control, resistance and change in the post-emancipation Caribbean', História, Ciências, Saúde-Manguinho, 19 (2012) pp. 47-58. For details of the cholera epidemic in Jamaica in 1850 and 1851, see Kenneth F. Kiple and Brian Higgins, 'Cholera in mid-nineteenth century Jamaica', Jamaican Historical Review, 17 (1991) pp. 31-47, itself based heavily on the Reports of 1851,1852 and 1853 cited below

485 Geo II c. 4.

4941 Geo. III c. 16

50 The most recent survey of British maritime quarantine up to 1850 is found in John Booker, Maritime quarantine: the British experience, c. 1650-1900 (Aldershot, 2007) . For older surveys, see C.F. Mullett, 'A century of English quarantine, 1709-1825', Bulletin of the History of Medicine, 23 (1949) pp. 527-45; J.C. Mcdonald, 'The history of quarantine in Britain during the 19th century', ibid.25 (1951) pp. 22-44. 5158 Geo III c. 25; 4 Geo IV c. 23. 
52 Watchman, 28 December 1831, 'Resolutions'; TNA, CO137/181, f. 208r-13r, Belmore to Goderich, 18 January 1832, and Council Minutes, 28 December 1831, and Proclamation; Watchman 24 December 1831, 'Editorial'

53 Jamaica Archives, 2/6/12 (Minutes, Council, Kingston Corporation) 13 February 1832; Watchman, 4 January 1832, 'Proclamation'

54 Watchman, 24 December 1831, 'Editorial'

55 Watchman, 28 March 1832, 'The Health officer'

56 Watchman, 31 March 1832, 'Editorial'

57 Watchman, 4 April 1832, 'The Cholera'

58 Watchman, 22 September 1832, ‘A Proclamation'; TNA, CO137/83 f. 33r-35v, Sligo to Goderich, 18 August 1832, and 'Proclamation'

59 TNA, CO 140/122, pp. 101, 102; Watchman, 5 May 1832, 'Proceedings in Assembly' for 29 March 1832,3 April 1832.

60 Hall, Free Jamaica pp. 52-8; Green, British slave emancipation pp. 261-93; Eisner, Jamaica, 1830-1930 pp. 143-7. For an example of how concerns about contagion and infection were, by contrast, exploited to prevent the immigration of undesirable convicts to Australia, see Katherine Foxhall, 'Fever, immigration and quarantine in New South Wales, 1837-40', Social History of Medicine, 24 (2012) pp. 624-642

61 TNA, CO 140/131 pp. 24, 132-3, 147, 158, 166-7, 236-7, 239

624 Vic c. 32

63 TNA, CO140/131 pp. 288-9, 311; Morning Journal, 12 December 1840, 'Proceedings in Council’; 15 December 1840, 'Editorial'; 16 December 1840, 'Proceedings in Council'; 18 December 1840, 'Proceedings in Council'.

64 Morning Journal, 17 October 1840, 'Notice', and 10 December 1840, 'Editorial';

658 Vic c. 9

66 Fryar, 'Moral politics', pp. 598-618; Juanita De Barros, Reproducing the British Caribbean: sex, gender, and population politics after slavery (Chapel Hill, NC, 2014) pp. 28-36

67 CBH Report, pp. 70-1. For Milroy's report on quarantine, see Gavin Milroy, Report on the Cholera in Jamaica, and on the general sanitary condition and wants of the island (London, 1853) pp. 80-9

68 CBH Report, p. 117

69 CBH Report, pp. 284-9 
70 Heuman, Black and White pp. 57-63, 138-9; Wilmot, 'Bondage', pp. 308-15; Paton, No bond pp. 92, 110-17; Smith, Insanity pp. 38-41, 50-3

71 UK Parliamentary Papers 1854 (235), 'A copy of the Report made by Dr Milroy to the Colonial Office on the cholera epidemic in Jamaica, 1850-51', [hereafter PP 1854 (235), 'Report'] pp. 117-8, Board of Health to Mayor, 24 November 1849

72 TNA, CO $140 / 141$ p. 60,69

73 PP 1854 (235), ‘Report', p. 7

74 PP 1854 (235), ‘Report', p. 14

75 PP 1854 (235), 'Report', pp. 25-6

76 PP 1854 (235), ‘Report', pp. 38-47

77 PP 1854 (235), ‘Report’, pp. 80-1

78 CBH Report, pp. 179-80

79 CBH Report, pp. 11-12

80 CBH Report, p. 71. Milroy likewise concluded in his 1853 Report 'that the most experienced health officers in the island are of opinion that the existing practice of quarantine affords little or no protection to the public health, while it proves highly inconvenient and vexatious to shipping and has on more than one occasion been productive of most distressing consequences' (emphasis mine): Milroy, Report on the Cholera p. 88 81 CBH Report, pp. 40-64. Emphasis in the original.

82 CBH Report, pp. 64-115

83 CBH Report, p. 114

84 CBH Report, 'Appendix', p. 23

85 PP 1854 (235), 'Report', pp. 145, 146

86 Colonial Standard, 30 April 1851, 'Editorial'.

87 Colonial Standard, 2 May 1851, 'Proceedings', 1 May 1851.

88 Fryar, 'Moral politics', p. 618n

89 PP 1854 (235), 'Report', p. 143

90 PP 1854 (235), 'Report', p. 146

91 PP 1854 (235), 'Report', p. 147 
'Public health in Jamaica'

92 PP 1861 (544), ‘Abstracts of Returns of Information on the laws of Quarantine', pp. 49, 63-6. For sanitary reform and public health in Jamaica after 1850, see Margaret Jones, Public Health in Jamaica, 1850-1940: neglect, philanthropy and development (Jamaica, 2013) pp. 11-32, 64-72

93 Goold and Kelly, 'Introduction', p. 4 